\title{
KULEUVEN
}

First year university students' self-perception of ICT skills: Do learning styles matter?

The final publication is available at http://link.springer.com/article/10.1007\%2Fs10639-010-9149-1 or by using

Verhoeven, Jef C., Heerwegh, Dirk. \& De Wit, Kurt_(2012) "First year university students' self-perception of ICT skills: Do learning styles matter?" Education and Information Technologies. Vol. 17 (1): $109-133$. DOI: 10.1007/s10639-010-9149-1 
The final publication is available at http://link.springer.com/article/10.1007\%2Fs10639-010-9149-1.

\section{First year university students' self-perception of ICT skills: Do learning styles matter?}

\section{Jef C. Verhoeven, Dirk Heerwegh, Kurt De Wit ${ }^{1}$}

\section{Abstract}

Do ICT skills of freshmen change in six months at the university? What is the contribution of learning styles (or patterns) to the explanation of the variance in self-perceived ICT skills and the possible change in these skills? And what is the contribution of learning styles and of gender, social class, and ICT course attendance to the explanation of the variance in these skills? To answer these questions, data were collected in a panel research project that recruited 714 freshmen at a large Belgian university. The data show that the ability of the students to maintain a computer and to develop a website improves at the university but not the ability to use the Internet or to apply basic ICT skills. The analyses show that there is a link, albeit weak, between learning styles and self-perceived ICT skills. Learning styles can partially explain differences between groups of students with different characteristics. The data show that having a certain learning style might influence the perception of students of their ICT skill, but learning styles do not allow one to predict the change in the self-perceived ICT skills of the students.

\section{Introduction}

Every year thousands of young students register at universities. They have already had some experience with Information and Communication Technologies (ICTs) but nevertheless, at the end of the first year, it becomes clear that not all of them have the necessary skills to work with all of the ICT resources available to them. In a world which is increasingly driven by ICT, this is a regrettable fact. The question is, therefore, if we can support university freshmen in learning how to handle ICT (see also Kirkwood and Price 2005).

\footnotetext{
1 J. C. Verhoeven, D. Heerwegh

Centre for Sociological Research, University of Leuven, Parkstraat 45 bus 3601, 3000 Leuven, Belgium

e-mail: jef.verhoeven@soc.kuleuven.be

D. Heerwegh

e-mail: dirk.heerwegh@soc.kuleuven.be

K. De Wit

Office for Educational Policy, University of Leuven, Krakenstraat 3 bus 5200, 3000 Leuven, Belgium e-mail: kurt.dewit@dowb.kuleuven.be
} 
But do freshmen really need that support? Indeed, these technologies have long been such an omnipresent part of life that we take for granted that freshmen arriving at the university are familiar with the most important techniques needed to handle a computer. This is true for many of them, but, as we will show later, a considerable number are not very proficient in computer use and ICT (see also Kennedy et al. 2008). Strømsø et al. (2004) showed that this is a problem not only for freshmen but also for more experienced students. A similar development is reported by Kaminski et al. (2009). Graduating seniors reported a decrease in the use of databases, Web animation, programming, desktop publishing, digital video, and digital audio in comparison with their use as freshmen. Moreover, they admitted that they had a very superficial knowledge about these techniques. ICT proficiency does not seem necessarily to improve by a longer stay at the university. This is a regrettable conclusion because today a job for graduates that does not involve computers is almost unthinkable.

Computer and ICT proficiency is, for many students, something acquired outside the formal school structure. In our research, for instance, $81 \%$ of our sample had not attended specific ICT classes in secondary school. This might well indicate that ICT proficiency is not associated with the normal school procedures for learning and, consequently, not with the learning styles that guide school learning. Nevertheless, learning content that has no formal recognition in the school does not necessarily escape the learning styles a student has acquired. Research has shown that learning styles are associated with examination results and learning outcomes, although there is also research available that shows the opposite (Sheard and Lynch 2003, p. 246; Boyle et al. 2003, p. 287). Vermunt (2005) and Vermunt and Vermetten (2004) cite studies that show that some learning styles are connected with strong examination results and others with weak results: students with a deep learning pattern achieved better than did students with a surface pattern. They also state that meaning-directed learning related positively with examination results, while reproduction-directed learning correlated negatively with them. Hwu (2003) and Battalio (2007) contend that the knowledge of learning patterns of students permits one to make a better forecast of learning outcomes and that learning patterns affect performance in some courses.

In other words, students who enter a university have already acquired learning styles, but not every learning style is equally appropriate to achieve success at university. Currently, universities offer their students a digital learning environment (often based on Blackboard software). However, it is unclear whether students have the necessary ICT skills to benefit 
from this digital learning environment in a useful way, and whether they have the appropriate learning styles to train themselves and improve themselves in order to make meaningful use of the digital learning environment for their studies. If some learning styles better improve the acquisition of ICT skills than others, it might be important for universities to differentiate between the ways in which they try to impart ICT skills to students in accordance with their learning styles.

In this article, we want to focus on university freshmen's self-perceived ICT skills, the way these do or do not change in the first year at university, and the possible role of learning styles in explaining these (changes in) skills. If it is true that learning styles are meaningful for learning outcomes and examination results, we want to know whether there is a link between learning styles and self-perceived ICT skills among freshmen. Indeed, freshmen enter a new study environment in which ICT plays an important role. Most of them have become acquainted with ICT at home and/or at school (although this experience may vary considerably among them), but at the university computer use is something that belongs to daily life, which is new to them. Does this change imply that ICT skills develop during the first year at the university? And, if so, to what extent is there a relation between students' learning styles and the change in their ICT skills? Moreover, what is the impact of gender, social class, and having to take an ICT-oriented course?

We will answer these questions as follows. In the next section, we will describe what is understood by learning styles, what they might mean for human behaviour, and what research questions they have inspired. Then we will present our methodology. In the following five sections, we will present the results of this research. Finally, we will discuss these results and draw some conclusions.

\section{Learning styles}

Learning styles are "the characteristic behaviours of learners that serve as relatively stable indicators of how they perceive, interact with, and respond to the learning environment" (J.W. Keefe, quote by Wang et al. 2001, p. 76).

Although researchers may agree on this general definition, they present very different categories of learning styles. Jan Smith (2001) for instance discerns four learning styles and discusses their consequences for curriculum delivery. Some of these ways of knowledge 
transfer are valued more highly than others, which might have consequences for the way knowledge is transferred in classrooms.

In addition to these different classifications, several research instruments were developed to study these learning styles (see Sabry and Baldwin 2003; Alty et al. 2006; Graf et al. 2008; Ross et al. 2001; Wang et al., 2001; Zualkernan et al. 2006; Vermunt 1994). In this article, we use the Inventory of Learning Styles (ILS) by Vermunt. There are several reasons for this choice. First, it opens a wide description of the different steps students have to make when they learn; second, although the learning styles are linked with class processes, the ILS also covers self-regulated learning, which is important for the current study since use of computer and ICT skills could also be learned outside of school; third, the instrument receives clear support from other researchers (e.g. Boyle et al. 2003, Coffield et al. 2004, p. 139).

The ILS divides the learning process of students into four domains. The first domain focuses on the collection of knowledge or processing strategies: "deep processing" is associated with a critical view on knowledge offered in textbooks and classes, "stepwise processing" with systematic repetition and memorisation, and "concrete processing" with connecting new knowledge to daily experiences.

The second domain focuses on regulation strategies: students rely more or less on their own judgement (self-regulation) to take the different steps in the learning process, or they follow the prescriptions given by the textbook and/or teacher (external regulation). However, not all students regulate their own study process or are inspired by others and might lack any form of regulation (lack of regulation).

The third domain encompasses the learning orientations. Learning may be done for many reasons: because of interest in what is learned (personally interested), because study leads to a certificate (certification directed), or because of requirements of their later occupation (vocation directed). Moreover, students might just sit in a course because they want to prove to themselves that they are able to do these studies (self-test directed) or may doubt about their ability to finish a course successfully (ambivalent).

The fourth domain focuses on conceptions of learning. Learners have ideas about learning that might influence the learning process. The ILS discerns five types of conceptions of 
learning: 1) construction of knowledge; 2) intake of knowledge, 3) use of knowledge; 4) opinion about what a teacher is supposed to do for the learner, and 5) learning in cooperation or not.

These different facets of learning are the basis for Vermunt's four coherent learning styles (also called "learning patterns"): meaning-directed, reproduction-directed, applicationdirected and undirected (Vermetten et al. 1999; Vermunt 2005). We will use two of these learning patterns (meaning-directed and application-directed) in our analyses, and will return to them in more detail in the description of the methods of this research. Based on factor analysis (Vermunt and Vermetten 2004, p. 367), eight learning styles, each referring to different domains of the learning process, are presented in Figure 1 as the components of these two learning patterns.

Figure 1. Learning patterns and composing learning styles in relation to four domains of the learning process

\begin{tabular}{|l|l|l|}
\hline Domains of learning process & Meaning-directed learning pattern & $\begin{array}{l}\text { Application-directed learning } \\
\text { pattern }\end{array}$ \\
\hline Processing strategies & Relating and structuring & - \\
& Critical processing & - \\
Concrete processing & - \\
Regulation strategies & Self-regulation & - \\
Conceptions of learning & Personally interested & Vocation-oriented \\
\hline
\end{tabular}

The question is, then, whether there is an interaction between learning styles and using ICT for study. Research has shown that there is indeed some interaction between learning styles and computer use, but provides us with no definite answer with regard to the strength or direction of this link. A positive interaction is for instance found by Shen et al. (2008) who showed that collaborative examinations in an on-line environment reduced surface learning and improved the interactions in a learning community of university students. Chapman and Calhoun (2006) observed that medical students are expected to score highly on abstract, active and individual learning constructs after they had been trained in a problem-based and computer-assisted learning environment (compare Masiello et al. 2005). On the other hand, Ross et al. (2001) found in two university-level computer application courses that dominant "abstract random" learners performed the poorest of all groups while the "abstract sequential" and the "concrete sequential" groups had the best results. Zualkernan et al. (2006) calculated that computer science and engineering students with an active learning orientation achieved higher grades in the programming class than did the others. 
Although these research results are not always consistent, they do show that there might be a relationship between learning styles, on the one hand, and computer use and ICT skills, on the other. The purpose of this article is to study this link among university freshmen; not for specific types of ICT or particular study environments (as is usually the case in relevant literature), but for the self-perceived basic skills when using ICT in general. In other words, we do not focus on a specific context, but on the role of learning styles in the general context of using ICT for study. However, we do include a variable indicating whether students had to take a compulsory ICT-oriented course at the university (as is the case for students studying bioengineering, civil engineering, physics, mathematics and medicine, for example), as we expect these students will rely more on computers for their studies than will other students.

When investigating the link between learning styles and ICT competence, it is important to take into account other factors that could influence this competence. The digital differentiation approach (van Dijk 2006) sees gender, social class and age as key factors in explaining divisions as far as the use of ICT is concerned. Social actors approach ICT from their own standpoints and so define how they want to use ICT in their lives depending on their life situation. In our research, age was omitted because most of the students were similar in this respect. Social class was included, with the employment situation of the students' parents as the indicator (see below). Gender was also included, as researchers still find differences between the sexes in the use of and attitude towards ICT, although the old divide between ICT-poor women and ICT-rich men has disappeared (Losh 2004; van Braak 2004; Becker 2006; Wang, et al. 2009).

Hence, we set out to answer the following questions:

1) What do learning patterns contribute to the explanation of the initial level of the (selfperceived) ICT skills of students?

2) Does the level of the ICT skills of freshmen change during the first six months at university? We assumed the ICT skills of the students would change, because education in universities is organised differently than it is in secondary schools (e.g. a digital learning environment).

3) If there is a change, to what extent do learning patterns explain this?

4) Does the explanation of the level, or the change in the level, of ICT skills improve when we add gender or social class, and ICT course attendance to our model? 


\section{Methodology}

When students enter university, they have already attained a certain level of ICT skills, acquired in secondary school or outside the formal education system. Learning styles might have an influence on this initial level of competence. But at university, their ICT skills might change. In order to investigate this possible change, we developed a research design enabling us to determine whether there was a development in ICT use and skills. At the beginning of the academic year, September-October 2004, we offered all freshmen of one of the largest universities of Belgium an on-line questionnaire asking them to describe their computer use and ICT skills in secondary school. We repeated this in March-April 2005 with the same questions but now about the university. The students received three reminders for each questionnaire. Our objective was to determine if any change in their self-perception of their ICT use and skills had occurred. 1,827 freshmen responded to the first questionnaire $(36.8 \%$ of the 4,960 registered) and 2,212 to the second (44.6\%). In order to check whether our sample was not disturbed by students who did not have a computer (although computers are available at many places at this university), the same questionnaire of 2004 was sent on paper to a sample of 300 freshmen. $54.6 \%$ of them responded. All of them had a computer, and $98 \%$ had access to the Internet. This is an acceptable, albeit not perfect, indication that most of the students could answer the on-line questionnaire.

Our analysis requires data from both surveys on the individual level. 714 students $(14.4 \%$ of the freshmen population) were found to have answered both questionnaires. To be confident that our sample was representative of the freshman population, the sample distribution of the following variables were checked against the population distribution: gender, housing, field of study, secondary study of freshmen, employment and education of the parents, having a study grant, and participation in an introduction day organized by the university. In our sample, we found a significant deviation from the distribution of the freshmen in the university as far as gender, housing, and field of study were concerned. For these variables, a weight variable was calculated in order to correct our analyses.

Both questionnaires collected information about computer use, ICT skills and attitudes toward ICT on the one hand, and learning styles on the other hand. In order not to make the questionnaires too burdensome, not all of the learning style variables of the ILS were included 
in the questionnaires. Indeed, many on-line questionnaires are presented to respondents, but there is no guarantee that they will be answered. Brevity is certainly one of the factors that might help to obtain a higher response ratio. Therefore we asked about different aspects of learning styles in 2004 and 2005. Although this is not the most elegant way to look at learning styles, Vermunt and Vermetten (2004) have shown that there is some consistency in learning styles among students. Since the time between answering the two questionnaires was six months or less, we may hypothesise that there is some consistency in the learning styles.

This brought us to the following explanatory model.

Figure 2: Explanatory model

\begin{tabular}{|c|c|}
\hline \multicolumn{2}{|r|}{ Dependent variables } \\
\hline - meaning-directed learning pattern & Self-perceived ICT competence (skills) \\
\hline Relating and structuring & - competence to maintain a computer \\
\hline Self-regulation of learning processes & and change of this competence \\
\hline Construction of knowledge & - $\quad$ competence to use the Internet and \\
\hline Personal interest & change of this competence \\
\hline Concrete processing + & - competence to develop a website \\
\hline - female or male (dummy) or social & and change of this competence \\
\hline class (dummy) & - basic skills to work with computer \\
\hline - student attends ICT related course & programmes and change of this competence \\
\hline or not (dummy) & \\
\hline \multicolumn{2}{|l|}{ - application-directed learning pattern } \\
\hline \multicolumn{2}{|l|}{ Use of knowledge } \\
\hline \multicolumn{2}{|l|}{ Vocational directed } \\
\hline \multicolumn{2}{|l|}{ Certificate directed } \\
\hline \multicolumn{2}{|l|}{ Self-test directed +} \\
\hline \multicolumn{2}{|l|}{ - female or male (dummy) or } \\
\hline \multicolumn{2}{|l|}{ social class (dummy) } \\
\hline - student attends ICT related & \\
\hline course or not (dummy) & \\
\hline
\end{tabular}

\subsection{Dependent variables}

We measured self-perceived computer skill by four scales based on 19 items suggested by Van Braak (2004). More specifically, we used these items to measure four types of ICT skills, i.e., basic ICT skills, maintenance skills, website-building skills, and Internet skills. Because an exploratory factor analysis (EFA) with Mplus 4.0 revealed that six items either loaded on more than one factor or did not load on any factor at all, they were removed from the analysis. We conducted a confirmatory factor analysis (CFA) with Mplus 4.0 to evaluate the fit of the four-factor model, which led us to allow one error covariance between two items measuring 
different skills in spreadsheets. These two items measured abilities within the same type of software, so one error covariance was acceptable.

The model fit was adequate with a TLI (Tucker Lewis Index) value of .992, an RMSEA (root mean square of error approximation) value of .05, and an SRMR (standardized root mean square residual) value of $.048 .^{2}$.

Figure 3: Results of the confirmatory factor analysis of ICT skills

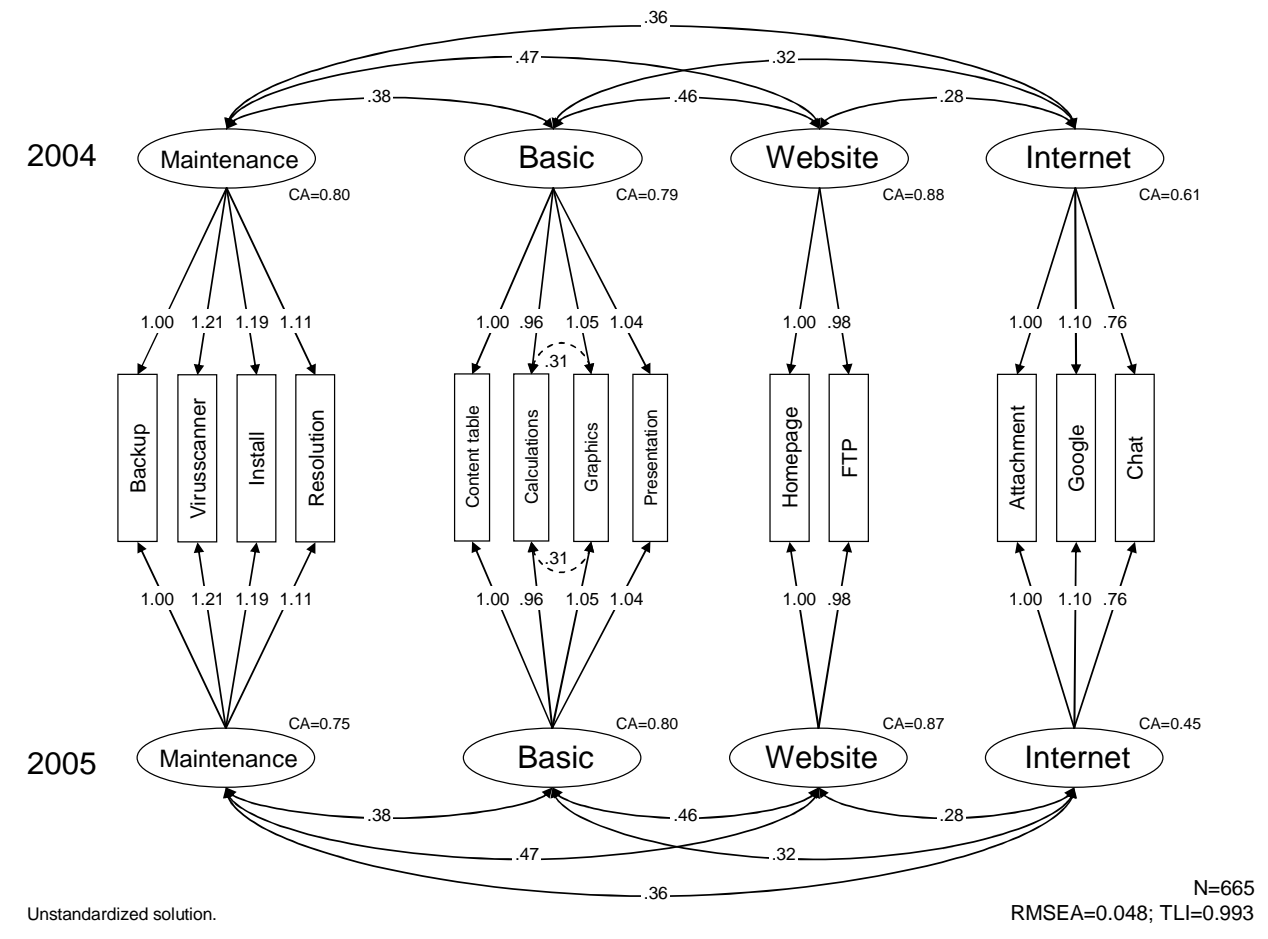

For both surveys, the following scales were constructed: 1) a scale to measure the ability to maintain a computer (four items, such as "I can install a virus scanner"); 2) a scale to measure the basic skills to work with a computer program (four items, such as "Using a word processing programme, I can write a report with an automatic table of contents"); 3) a scale to measure the ability to develop a website (two items were used: "I can publish a page on the web (FTP)" and "I can create my own home page using web design software (e.g. Frontpage, Dreamweaver, ...); and 4) a scale to measure the ability to use the Internet (three items, such as "I can search for web pages using search engines (Google, Altavista, ...)".

\subsection{Independent variables}

\footnotetext{
2 TLI values above 0.90 , RMSEA values below .08, and SRMR values below 0.10 are traditionally considered to indicate good model fit (Vandenberg and Lance 2002, p. 44-45).
} 
For the reasons indicated above, we decided to use the ILS, but not integrally although most items were offered to the students when we consider both surveys together. We confine our analysis to two learning patterns, which have also been identified by several other authors (Vermunt 1996; Wierstra and Berends 1996; Boyle et al. 2003; Vermunt and Vermetten 2004): the meaning-directed and the application-directed learning patterns. Although it is quite possible that students manifest both, they are certainly not identical. How are these two learning patterns composed?

Because our analyses were restricted to two factors (meaning-directed and applicationdirected), only the relevant 9 scales were included in the exploratory factor analysis (see also Figure 1): relating and structuring, concrete processing, self-regulation, construction of knowledge, use of knowledge, personally interested, certificate-oriented, self-test-oriented, and vocation-oriented. The factor analysis was conducted with the number of factors a priori set to two, with priors set to "squared multiple correlations", and with a promax rotation. The eigenvalues of the two extracted factors were 2.28 and 1.21. The interfactor correlation was .22 , and the variance explained by each factor was 2.15 for Factor 1 and 1.53 for Factor 2. The factor loadings are presented in Table 1.

Table 1 Rotated factor pattern for the meaning-directed and the application-directed learning pattern (Standardized Regression Coefficients; Loadings $>-.25$ and $<.25$ omitted)

Factor1 Factor2

\begin{tabular}{lcc}
\hline Relating \& structuring & 0.72 & \\
Concrete processing & 0.69 & \\
Self-regulation & 0.76 & 0.31 \\
Construction of knowledge & 0.53 & 0.61 \\
Use of knowledge & & \\
Personally interested & 0.39 & 0.55 \\
Certificate-oriented & & 0.53 \\
Self-test-oriented & & 0.56 \\
Vocation-oriented & & \\
\hline
\end{tabular}

The results show that the variables 'relating and structuring', 'concrete processing', 'selfregulation', 'construction of knowledge', and 'personally interested' have substantial loadings on Factor 1, while the variables 'use of knowledge', 'certificate-oriented', 'self-test-oriented', and 'vocation-oriented' have substantial loadings on Factor 2. Therefore, Factor 1 could be identified as the meaning-directed factor and Factor 2 as the application-directed factor. From 
the eigenvalues and the number of items with substantial loadings, it can be deduced that the meaning-directed factor is a more well-defined factor than the application-directed factor. Using these results as a basis, we constructed the meaning-directed factor as a sum score (Likert-type scale) of the scales in Factor 1. Likewise, the application-directed factor was constructed as a sum score (Likert-type scale) of the scales in Factor 2.

For each of them, we give the main labels and an example of the items (Vermunt and Vermetten, 2004) used in the scales in Figure 4.

Figure 4. ILS learning patterns, subscales, and item examples

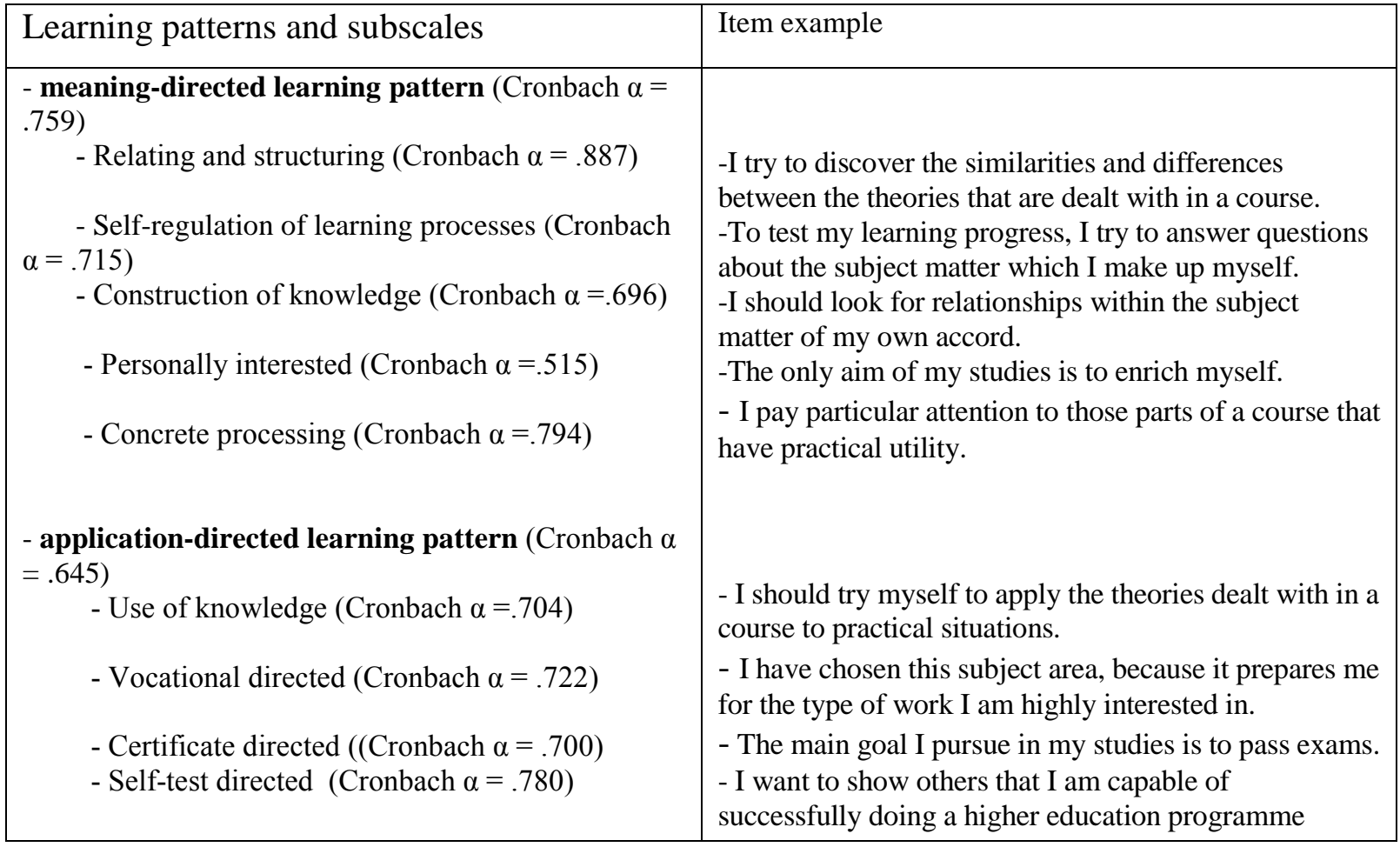

As was explained in the previous section, next to the learning styles three other variables might influence the (change in) self-perceived ICT skills: gender, social class, and attendance of an ICT-related course. Social class is represented in this analysis as a dummy: a score of 1 represents students with one or both parents being blue-collar workers, all other students were scored 0 . Of course, this is a rather simplistic representation of the class structure. Nevertheless, it allows us to check whether the cultural and economic differences between workers and other groups are also apparent in the ICT competences of the students. Attendance of an ICT-related course may result in the positive consequence that students who have to attend such a course have more opportunities to practise some ICT competences. Students who attended an ICT course at university were scored 1 , the others scored 0 . Regression analyses was used to 
determine whether and to what degree these variables explain self-perceived ICT skills of students as well as changes in these variables after six months at the university.

The application of these additional variables in our model is interesting because there is no correlation between meaning-directed learning, on the on hand, and gender $(\mathrm{r}=-0.039 ; \mathrm{p}=$ $.36)$, attendance of an ICT-related course $(\mathrm{r}=-.039 ; \mathrm{p}=.33)$ or belonging to the working class $(\mathrm{r}=-.003 ; \mathrm{p}=.94)$, on the other. Nor is there a correlation between application-directed learning, on the one hand, and gender $(\mathrm{r}=-.039 ; \mathrm{p}=.32)$, attendance of an ICT-related course $(r=.029 ; \mathrm{p}=.45)$, or belonging to the working class $(\mathrm{r}=.002, \mathrm{p}=.96)$, on the other.

In the analysis, we first constructed a model using only learning styles as predictor variables. In a second model, gender and ICT course attendance were added. A third model included learning styles and ICT course attendance too, but the gender variable was replaced with social class.

In the next section, we will briefly describe the access students have to the internet and computers. In the subsequent sections, we will present the results of our three models.

\section{Access to the internet and computers}

When the students arrived at the university, 99\% had had a computer at home. Six months later the percentage was still the same. Nevertheless, the situation had changed. Before coming to university, $67 \%$ had this computer in their own room. Six months later only $30 \%$ were in that situation. The reason was that many of them (67\%) actually lived in rooms at the university and had a personal computer there. Only $3 \%$ of those living in student housing had no computer in their rooms but did have one at home.

Also, most of the students had an Internet connection. At home, $96 \%$ of the students had an Internet link when they were in secondary school, and six months later all but two students had such a link. At the time of the survey, $63 \%$ of the students had access both at home and in their room at the university; $1 \%$ had a connection only in their rooms; and 35\% only at home. It is also important to note that, as far as basic computer equipment was concerned, there were no differences between the working-class students and the others. This was also true for the access to the Internet $\left(\chi^{2}=5.6 ; \mathrm{df}=3 ; \mathrm{p}=.13\right)$. Nevertheless, there was a difference between working-class students and the others in the kind of access to the Internet: 8\% of the working- 
class students had no broadband access, only $3 \%$ of the other students did not have it $\left(\chi^{2}=\right.$ $7.18 ; \mathrm{df}=1 ; \mathrm{p}=.007)$.

The place where the computer was mostly used differed in secondary school from where it was used at the university. About $95 \%$ of the students used the computer mostly at home when they were in secondary school but only $3 \%$ at school. At the university, these figures changed to $37 \%$ and $2 \%$, respectively, and $60 \%$ of students used the computer most of the time in their rooms.

Computer use was not integrated into daily school life during secondary school, but $82 \%$ of the students used it in some courses. At the university, this had changed: although only $52 \%$ of the students attended one or more courses in which ICT is important, all of the students used the computer daily.

In short, access to computers and the internet is (quasi) universal among students, and at the university they come to use them daily. Let us now turn to our three explanatory models to answer questions about the link between our predictor variables and self-perceived ICT skills.

\section{The meaning-directed learning pattern and ICT skills?}

Not many would expect a negative answer to this question. Indeed, in order to maintain a computer, one must be capable of seeing the unit as a whole. Developing a website presumes the capacity to apply principles learned in books or elsewhere in another, albeit similar, environment. Application of the basic ICT skills assumes that one is prepared to look for relationships between the different programs, and using the internet for chatting or e-mail assumes that one is personally interested in this action. Although these links are present, it should not be forgotten that the questions about learning styles in our questionnaire were not connected with the self-perception of ICT skills. They were offered to the students as though they were intended for a general assessment of their learning styles. The questions about ICT skills were asked separately. Indeed, there was no reason for the students to think that the researchers were looking for a link between learning patterns and ICT skills. Although we expected that learning styles should help to predict something about ICT skills, the data did not deliver overwhelming evidence. 
When looking at the meaning-directed learning pattern alone (model 1), the results show that, in secondary school, the five components of the meaning-directed learning style do not explain very much of the capacity of the students to maintain a computer $\left(\mathrm{R}^{2}=.038\right)$, to develop a website $\left(\mathrm{R}^{2}=.027\right)$, to use basic ICT skills $\left(\mathrm{R}^{2}=.046\right)$, or to use the Internet $\left(\mathrm{R}^{2}=\right.$ .033). At the university, meaning-directed learning explains a little more of the selfperception of ICT skills but not very much (respectively $\mathrm{R}^{2}=.06 ; .032 ; .058$; and .035). Even of the two forms of self-perception of ICT skills that changed significantly (see Section 7), i.e., maintenance of the computer and the use of basic ICT skills, this learning pattern could explain only $2.3 \%$ of the variance of the change in computer maintenance abilities and nothing of the variance in the change in the use of basic ICT capacities.

However, the second model in which the meaning-directed pattern is linked with gender and the attendance of an obligatory ICT-related course is more able to explain the self-perception of ICT skills among students (see Table 2). 
Table 2 Meaning-directed learning, gender and ICT course as predictors of self-perception of ICT skills (regression analysis; unstandardised parameters)

\begin{tabular}{|c|c|c|c|c|c|c|c|c|c|c|c|c|}
\hline \multirow{3}{*}{$\begin{array}{l}\text { Predictors } \\
\text { Meaning-directed } \\
\text { learning pattern } \\
\end{array}$} & \multicolumn{12}{|c|}{ Self-perception of ICT competence } \\
\hline & \multicolumn{3}{|c|}{ Maintain a computer } & \multicolumn{3}{|c|}{ Develop a site } & \multicolumn{3}{|c|}{ Use basic ICT skills } & \multicolumn{3}{|c|}{ Internet use } \\
\hline & $\begin{array}{l}\beta \text { Secondary } \\
\text { school }\end{array}$ & $\begin{array}{l}\beta \\
\text { University }\end{array}$ & $\begin{array}{l}\beta \\
\text { change }\end{array}$ & $\begin{array}{l}\beta \text { Secondary } \\
\text { school }\end{array}$ & $\beta$ University & $\begin{array}{l}\beta \\
\text { change }\end{array}$ & $\begin{array}{l}\beta \text { Secondary } \\
\text { school }\end{array}$ & $\begin{array}{l}\beta \\
\text { University }\end{array}$ & $\begin{array}{l}\beta \\
\text { change }\end{array}$ & $\begin{array}{l}\beta \text { Secondary } \\
\text { school }\end{array}$ & $\begin{array}{l}\beta \\
\text { University }\end{array}$ & $\begin{array}{l}\beta \\
\text { change }\end{array}$ \\
\hline Intercept & 3.26 & 3.24 & 0.02 & 1.63 & 2.31 & - & 2.64 & 2.69 & - & 5.00 & 4.97 & - \\
\hline $\begin{array}{l}\text { Relating and } \\
\text { structuring }\end{array}$ & - & - & - & $0.17 *$ & - & - & - & $0.14 *$ & - & - & $0.05^{*}$ & - \\
\hline Self-regulation & - & - & - & - & - & - & - & - & - & - & - & - \\
\hline $\begin{array}{l}\text { Construction of } \\
\text { knowledge }\end{array}$ & $0.30 * * *$ & $0.20 * *$ & $-0.11 *$ & - & - & - & $0.25 * * *$ & $0.20 * *$ & - & - & - & - \\
\hline Personally interested & $-0.20 * *$ & $-0.13 *$ & - & - & - & - & - & - & - & $-0.13 * * *$ & $-0.10 * * *$ & - \\
\hline Concrete processing & - & - & - & $0.17 *$ & $0.20 *$ & - & - & - & - & - & & - \\
\hline Female & $-0.90 * *$ & $-0.70 * * *$ & $0.19 * * *$ & $-0.67 * * *$ & $-0.81 * * *$ & - & $-0.46 * * *$ & $-0.41 * * *$ & - & - & $-0.06 *$ & - \\
\hline ICT course & $0.20 *$ & $0.17 *$ & - & $0.25 * *$ & $0.23 *$ & - & - & - & - & - & - & - \\
\hline $\mathrm{R}^{2}$ & 0.20 & 0.20 & 0.04 & 0.11 & 0.13 & - & 0.10 & 0.11 & - & 0.04 & 0.04 & - \\
\hline $\mathrm{F}$ & $22.28 * * *$ & $21.20 * * *$ & $3.94 * * *$ & $10.62 * * *$ & $13.03 * * *$ & - & $9.22 * * *$ & $9.91 * * *$ & - & $3.17 * *$ & $4.04 * * *$ & - \\
\hline
\end{tabular}


Model 2 can explain more the maintenance of the computer (20\% of the variance in secondary school and at the university) than developing a website (respectively $11 \%$ and $13 \%$ ) or the use of basic ICT skills (respectively $\mathrm{R}^{2}=.10$ and .11 ). For internet use no more than $4 \%$ of the variance in secondary school and at the university are explained by this model. This was to be expected because internet use among students was very popular among students not only in secondary school but also at the university.

The most influential factor in this model is gender while learning styles play a minor role. The main message here is that male students consider themselves significantly more able than female students to maintain a computer, to develop a website, and to use basic ICT skills. This was so in secondary school and remains so at the university. Male students at the university also think that they are slightly more competent in using the Internet than women $(\beta=-0.06)$, which was not the case in secondary school.

The students who had to take an ICT course at the university considered themselves better in maintaining a computer and developing a website than did the others, which perception is present both in secondary school and at the university. This difference is not observed for the use of basic ICT skills and the use of the Internet.

In the second model, learning styles play a significant role in the explanation of the selfperception of ICT skills, but not for all ICT skills and only rarely in secondary school and university together. Students who prefer to work actively to detect knowledge (construction of knowledge) consider themselves more able to maintain a computer and apply basic ICT skills. Those who are personally interested in what they study, saw themselves as being less competent in maintaining a computer and using the Internet than did the other students. Perhaps, ICT is for them secondary; the content of the studied discipline being of primary importance. Students who look for information somewhere else than their text books or learn from other sources than those offered at school or university (concrete processing) considered themselves more competent in developing a website than did the other students. It is remarkable that the students who try to detect relations in their courses saw themselves as having been more competent in developing a website in secondary school but more competent in the use of ICT basic skills and the Internet at the university. 
Also notable is that those who scored high on self-regulation did not seem to think that they had significantly more ICT skills than did the others. Intrigued by these figures, we wanted to know whether those who scored high on self-regulated learning would also score high on the idea that they had learned most about computer usage and ICT by themselves. The relation was, indeed, found, but it was not very strong $(\mathrm{r}=.124 ; \mathrm{p}=.0012)$. This is surprising. In view of the average score on ICT self-study (score 4.02 out of 5), however, this rather weak correlation becomes understandable. Most of the students in secondary school believe that what they had learned about ICT was done without much help. The other persons who might have helped studying ICT scored much lower than did the respondents themselves: help from teachers scored 2.67 out of 5 , friends 3.29 , father 2.62, mother 1.69 , brother 2.63 , sister 2.01, other persons 2.91. In other words, the average label for the support from others is "very little" or "a little". Since most believe that they had learned most of it by themselves, not much differentiation was possible in relation to self-regulated learning.

Replacing the variable of gender by socio-professional category of the parents (model 3) shows that there is no significant difference between those students whose parents belong to the working class and the others, and the self-perception of ICT skills seems to be the same for both. Attending an ICT course had a similar influence for ICT skills, and this also applies for the construction-of-knowledge learning pattern. Interest in the subject matter of the discipline has, as above, a negative influence on the ability to use the Internet and in secondary school also on ability to maintain a computer. Those who learn from applying a course (concrete processing) consider themselves to be more able to maintain a computer or develop a website. Whether students try to link elements of their courses or not (relating) does not contribute to a better understanding of the ICT skills.

\section{The application-directed learning pattern and ICT skills?}

It will be hard to imagine a job for a graduate in the future that does not involve ICT. Therefore, it is quite reasonable to suggest that students who are studying because they want to do a particular job, want to earn a certificate, want to acquire useful knowledge, or want to prove that they are capable of studying at a university would be eager to learn how to maintain a computer, employ basic ICT skills, use the internet, or develop a website. Looking at the correlations between these variables in model 1, this hypothesis is supported for the ability to maintain a computer and the ability to use ICT basic skills (Pearson $\mathrm{r}$ is between .10 
and .18). We assume that these correlations are rather low because to students, maintaining a computer and using ICT basic skills probably belongs more to the world of leisure than the world of labour. The former hypothesis is also supported for the relationship between developing a website and the use of knowledge and vocation-oriented studying. Nevertheless, at the university there is no significant relation anymore between the four learning patterns and the use of internet. Indeed, the use of the Internet has become part of the daily life of nearly all of the students.

In spite of these positive relations, the learning styles of the application-directed learning pattern do not allow one to predict very much about the self-perception of the ICT skills. This model explains only $4 \%$ of the variance in maintaining the computer and only a little more for the use of the basic ICT skills (4.5\% in secondary school and 5\% at the university). It is even less for developing a website (1.5\% in secondary school and $1.7 \%$ at the university) and use of the Internet (1.8\% in secondary school). 
Table 3 Application-directed learning, gender and ICT course as predictors of self-perception of ICT skills (regression analysis; unstandardised parameters)

\begin{tabular}{|c|c|c|c|c|c|c|c|c|c|c|c|c|}
\hline \multirow{3}{*}{$\begin{array}{l}\text { Predictors } \\
\text { application-directed } \\
\text { learning pattern }\end{array}$} & \multicolumn{12}{|c|}{ Self-perception of ICT competence } \\
\hline & \multicolumn{3}{|c|}{ Maintain a computer } & \multicolumn{3}{|c|}{ Develop a site } & \multicolumn{3}{|c|}{ Use basic ICT skills } & \multicolumn{3}{|c|}{ Internet use } \\
\hline & $\begin{array}{l}\beta \text { Secondary } \\
\text { school }\end{array}$ & $\begin{array}{l}\beta \\
\text { University }\end{array}$ & $\begin{array}{l}\beta \\
\text { change }\end{array}$ & $\begin{array}{l}\beta \text { Secondary } \\
\text { school }\end{array}$ & $\begin{array}{l}\beta \\
\text { University }\end{array}$ & $\begin{array}{l}\beta \\
\text { change }\end{array}$ & $\begin{array}{l}\beta \text { Secondary } \\
\text { school }\end{array}$ & $\begin{array}{l}\beta \\
\text { University }\end{array}$ & $\begin{array}{l}\beta \\
\text { change }\end{array}$ & $\begin{array}{l}\beta \text { Secondary } \\
\text { school }\end{array}$ & $\begin{array}{l}\beta \\
\text { University }\end{array}$ & $\begin{array}{l}\beta \\
\text { change }\end{array}$ \\
\hline Intercept & 2.48 & 3.01 & 0.54 & 1.60 & 1.72 & - & 2.23 & 2.19 & - & 4.49 & - & - \\
\hline Use of knowledge & - & - & - & - & - & - & $0.16^{*}$ & $0.19 *$ & - & - & - & - \\
\hline Vocational directed & $0.19 * *$ & $0.13 *$ & - & $0.20 * *$ & $0.19 *$ & - & $0.13 *$ & - & - & - & - & - \\
\hline Certificate directed & - & $0.12 *$ & - & - & - & - & - & - & - & - & - & - \\
\hline Self-test directed & - & - & - & - & - & - & - & - & - & - & - & - \\
\hline Female & $-0.87 * * *$ & $-0.68 * * *$ & $0.17 * *$ & $-0.69 * * *$ & $-0.80 * * *$ & - & $-0.40 * * *$ & $-0.37 * * *$ & - & - & - & - \\
\hline ICT course & - & - & - & $0.20 *$ & - & - & - & - & - & - & - & - \\
\hline $\mathrm{R}^{2}$ & 0.19 & 0.17 & 0.03 & 0.10 & 0.11 & - & 0.08 & 0.09 & - & 0.02 & - & - \\
\hline $\mathrm{F}$ & $25.26 * * *$ & $21.63 * * *$ & $3.04 * *$ & $11.29 * * *$ & $12.95 * * *$ & - & $9.38 * * *$ & $9.82 * * *$ & - & $2.34 *$ & - & - \\
\hline
\end{tabular}


Adding gender and ICT-course attendance to this model improves the model (see Table 3). Now it explains $19 \%$ of the variance in self-perception of computer-maintenance skill in secondary school and $17 \%$ in the university. For developing a website, these figures are $10 \%$ and $11 \%$, respectively, and for the use of basic ICT skills $8 \%$ and $9 \%$. This model does not contribute very much to the explanation of Internet use: in secondary school only $2 \%$, and nothing at the university. ICT use is so widely spread among students that none of the learning styles, gender, or ICT-course attendance provide a better explanation of this behaviour.

Just as in the model with the meaning-directed learning pattern, the most important factor to explain these ICT skills is gender. As above, male students see themselves more familiar with computer maintenance, website development, and basic ICT skills than do female students. Attending ICT courses does not have this meaning. Only in secondary school does attendance of an ICT course at the university predict maintaining a computer and developing sites better. In other words, those who at the university are closer to ICT by attending ICT courses were already at secondary school more able to solve some ICT problems.

Students who study because they need that study for a particular profession later (vocational directed) assess their ability to maintain a computer, develop a website, or use the basic ICT skills higher than do the other students, but the latter only in secondary school, not at the university. Moreover, the use of basic ICT skills is found more among students who prefer to study because knowledge might deliver practical solutions for problems than among the others.

Self-test directedness and certificate-directed orientation have no significant effect on the selfperception of ICT skills, except for maintenance of computers. Certificate-oriented university students are slightly more inclined to think that they are good in computer maintenance than are other students. A reason for this might be that students who score high for studying to attain a certificate are more convinced that ICT is useful for doing his job $(r=.17 ; \mathrm{p}<.0001)$. This relationship is not very strong. This might be a consequence of the content of the variable "usefulness of ICT for work". This is focused on an assessment of the usefulness of a computer to be better organised, work faster, etc. The work of a student is mainly studying and the computer cannot replace study as such. Therefore we assume that usefulness of a 
computer is assessed by students within the context of their work, and here the computer is certainly not the most important instrument.

When the variable gender is replaced by social class (model 3), the model explains a little more of the variance in the self-perception of ICT skills than the model in which only four application-directed learning styles are present. Perception of the ability to maintain a computer in secondary school is explained for $5.2 \%$ of the variance, and in university for $4.7 \%$, the perception of the use of basic ICT skills respectively for 5\% and 5.4\%, the perception of developing a website for both periods $2.4 \%$, and the perception of Internet use only $2.3 \%$ in secondary school. The contribution of the social-class position of the students is not significant for any of the four skills studied. In other words, as far as these ICT skills are concerned, there is no difference between working-class students and the others.

7. The meaning-directed and application-directed learning patterns combined

Previous analyses made it clear that there is some link between parts of meaning-directed learning and parts of application-directed learning, on the one hand, and self-perception of ICT skills, on the other. If both can explain something of this phenomenon separately, it is valuable to investigate whether both together can explain more of it. Maintenance of a computer is explained up to $5.3 \%$ in secondary school and $6.3 \%$ at university by both learning patterns; the use of basic ICT skills is explained by $6.8 \%$ and $7.8 \%$, developing a website by $1.7 \%$ and $1.6 \%$, respectively, and the use of Internet by $2.4 \%$ in secondary school. Both learning patterns contribute significantly to a better understanding of the self-perception of ICT skills. Nevertheless, Table 4 shows that the second model in which gender differences and participation in an ICT course are included is more fruitful. Self-perception of the ability to maintain a computer is explained for $21 \%$ in secondary school and $20 \%$ at university by this model; the use of basic ICT skills for $11 \%$ and $12 \%$, development of a website for $9.5 \%$ and $11.2 \%$, respectively, and Internet use only for $3 \%$ in secondary school. As we noted above, Internet use is so widespread among students that the study of these variables do not contribute significantly to the explanation of Internet use. Once more, gender is an important factor to explain the difference between the self-perception of ICT skills. The figures in Table 4 show that the self-perception of ICT skills is much higher among the male students than among the female students. It is even so that male students have a more pronounced position 
than female students as far as maintenance of a computer and the development of a website are concerned. 
Table 4 Learning patterns, gender and ICT course as predictors of self-perception of ICT skills (regression analysis; unstandardised parameters)

\begin{tabular}{|c|c|c|c|c|c|c|c|c|c|c|c|c|}
\hline \multirow[t]{3}{*}{ Predictors } & \multicolumn{12}{|c|}{ Self perception of ICT competence } \\
\hline & \multicolumn{3}{|c|}{ Maintain a computer } & \multicolumn{3}{|c|}{ Develop a site } & \multicolumn{3}{|c|}{ Use basic ICT skills } & \multicolumn{3}{|c|}{ Internet use } \\
\hline & $\begin{array}{l}\beta \text { Secondary } \\
\text { school }\end{array}$ & $\begin{array}{l}\beta \\
\text { University }\end{array}$ & $\begin{array}{l}\beta \\
\text { change }\end{array}$ & $\begin{array}{l}\beta \text { Secondary } \\
\text { school }\end{array}$ & $\begin{array}{l}\beta \\
\text { University }\end{array}$ & $\begin{array}{l}\beta \\
\text { change }\end{array}$ & $\begin{array}{l}\beta \text { Secondary } \\
\text { school }\end{array}$ & $\begin{array}{l}\beta \\
\text { University }\end{array}$ & $\begin{array}{l}\beta \\
\text { change }\end{array}$ & $\begin{array}{l}\beta \text { Secondary } \\
\text { school }\end{array}$ & $\begin{array}{l}\beta \\
\text { University }\end{array}$ & $\begin{array}{l}\beta \\
\text { change }\end{array}$ \\
\hline Intercept & 2.08 & 2.40 & 0.33 & 1.09 & 1.38 & - & 1.60 & 1.51 & - & 4.66 & - & - \\
\hline $\begin{array}{l}\text { Meaning-directed } \\
\text { learning pattern }\end{array}$ & - & $0.31 * * *$ & $0.14 *$ & $0.23 *$ & - & - & $0.30 * * *$ & $0.34 * * *$ & - & $-0.07 *$ & - & - \\
\hline $\begin{array}{l}\text { Application-directed } \\
\text { learning pattern }\end{array}$ & $0.41 * * *$ & $0.27 * * *$ & $-0.14 *$ & & $0.21 *$ & - & $0.37 * * *$ & $0.37 * * *$ & - & $0.11 * *$ & - & - \\
\hline Female & $-0.87 * * *$ & $-0.68 * * *$ & $0.18 * *$ & $-0.67 * * *$ & $-0.82 * * *$ & - & $-0.40 * * *$ & $-0.36 * * *$ & - & - & - & - \\
\hline ICT course & $0.16^{*}$ & - & - & $0.21 *$ & - & - & - & - & - & - & - & - \\
\hline $\mathrm{R}^{2}$ & 0.21 & 0.20 & 0.04 & 0.10 & 0.11 & - & 0.11 & 0.12 & - & 0.03 & - & - \\
\hline $\mathrm{F}$ & $38.51 * * *$ & $35.53 * * *$ & $5.39 * * *$ & $15.58 * * *$ & $18.63 * * *$ & - & $17.43 * * *$ & $18.70 * * *$ & - & $3.87 * *$ & - & - \\
\hline
\end{tabular}


Students who have chosen a course in which ICT is compulsory scored higher in secondary school for maintaining a computer and for developing a website. This is not the case for the use of basic ICT skills and Internet use; and neither of these relationships was found at the university.

The two learning patterns have a remarkable influence on the self-perception of ICT skills. In secondary school, the students who scored higher on meaning-directed learning also scored significantly higher on developing a website and the use of basic skills but significantly lower on Internet use, which seems to suggest that students having a serious learning attitude are not so keen on using the Internet for chatting, e-mailing, and the like. Also students scoring high on application-directed learning score high in secondary school for maintaining a computer, using basic ICT skills, and the use of Internet, but they are not different from other students for developing a website. The situation after six months at the university is a little different. Students who scored high on meaning-directed learning and application-directed learning also scored high on maintaining a computer and using basic ICT skills. Both learning patterns do not help to predict Internet use. Developing a website, on the other hand, is more the favourite of those who scored high on application-directed learning but not on meaning-directed learning.

When the gender variable is replaced by social class (model 3), the two learning patterns permit us to predict the self-perception of ICT skills as in the model with gender. Nevertheless, the variable social class does not allow any prediction concerning the selfperception of ICT skills. Working-class students and other students seemed to think equally when they describe their ICT skills. This is not only so at university but also already at the end of secondary school.

8. The meaning-directed and application-directed learning patterns and change in ICT skills

The first question to be answered is whether there was some change between secondary school and university. Only for maintaining a computer (from score 3.64 to 3.98 out of $5 ; \mathrm{t}=$ -11.95; $\mathrm{p}$ <.0001) and developing a website (from score 2.09 to 2.32 out of $5 ; \mathrm{t}=6.11 ; \mathrm{p}$ $<.0001)$ change was observed. The skills of the students on these fields improved, although the score for the latter is still low and only a small number of students is interested in this action. Of course, this has some consequences for the predictive power of our models. Since 
there is no change in using the Internet (from score 4.85 in secondary school to 4.88 out of 5 in university; $\mathrm{t}=-1.66 ; \mathrm{df}=699 ; \mathrm{p}=.097$ ) and using basic ICT skills (from score 3.67 to 3.7; $\mathrm{t}=-0.89 ; \mathrm{df}=696 ; \mathrm{p}=.372)$ and since the change in developing a website concerns a small part of our sample, we found no evidence that our models could predict this change. Our data show only something about changes in maintaining a computer.

Good predictors for the improvement of maintenance of a computer are the gender variable and the learning style "construction of knowledge" in model 2 with meaning-directed learning patterns (see Table 2). The less students look for relationships within a subject the more they improve their self-perceived capacity for maintaining a computer. Indeed, students scoring high on construction of knowledge in secondary school and in university also scored high on maintaining a computer. This means that low scorers could improve. This is also so for the women, who scored low for maintaining a computer in secondary school and at the university and could improve at the university. If we replace the gender variable with the social class variable (model 3) no predictive power can be found for explaining change in maintaining a computer.

Focusing on the model with application-directed learning patterns, we found no evidence for explaining the change in maintaining a computer (see Table 3). None of the learning styles helps to predict the change in maintaining a computer, there being only evidence that women contribute the most for the improvement of maintaining a computer. When gender is replaced by social class in this model, no prediction can be made about the change in maintaining a computer.

Bringing both learning patterns in a model together with gender and participation in an ICT course, we found that $4 \%$ of the variance in change of maintaining a computer can be explained by this model (see Table 4). The change is mainly found among female students scoring high on meaning-directed learning and low on application-directed learning. If the gender variable is replaced by social class there is still $2 \%$ of the variance explained by the model, but no contribution is made by social class.

\section{Conclusion}


The main purpose of this article was, first, to determine whether learning styles and/or patterns contribute to the explanation of the variance in self-perceived ICT skills. Several researchers (e.g., Sheard and Lynch 2003; Evans and Waring 2006; Sun et al. 2008; Ross et al. 2001, Liegle and Janicki 2006, see Section 2) have shown a link between learning styles and ICT skills. In our research, we used ILS, an observation instrument for collecting information about general principles of learning in higher education. In principle, the items of this instrument might be used by students for each type of learning in progress. Although some sources mention changes in the learning styles applied by students, research has shown a great stability in learning styles during the learning development of students (Vermunt and Vermetten 2004, p. 373). Research has also shown that learning styles depend on the context in which they are applied. For instance, different learning styles are differently applied by students of law, economics, or natural sciences. And Vermunt and Vermetten (2004, p. 376) state: "learning patterns explained an important part of the variance in exam results, between 25 and $55 \%$ for the different subject areas and the regular university". Therefore, we expected that learning styles and/or patterns would explain important parts of the variance in ICT skills. This expectation was only partly confirmed. As reported above, the meaning-directed learning pattern explained at the most $4.6 \%$ of the ICT skills in secondary school and not more than $6 \%$ at the university, and the application-directed learning pattern explained even less.

Our second main question was about any change in the level of ICT skills. It has become clear in our research that the use of ICT for study increases considerably from secondary education to university. Only $11 \%$ of the students in our research had used a computer at least two or three times a week for study while at secondary school before arriving at university. At university this figure increased to $83 \%$. It is clear therefore, that the computer becomes a tool for daily use by students at university. However, we also found that this does not mean that the level of students' ICT skills increases. The use of the Internet and of basic ICT skills did not significantly change during the period studied, and although there were significant changes to the skills of maintaining a computer and the development of websites, the changes to the levels of these skills turned out to be rather small. The first six months at university are clearly devoted to fields of study other than ICT techniques. This does not mean that students do not learn about SAS, SPSS, Statistica, Blackboard, etc., but apparently the use of these programs is based on the knowledge that students have of ICT programs in general. 
As there is so little change to the level of ICT skills, it will come as no surprise that we found as an answer to our third question, that learning patterns do not explain much about the changes in the level of the ICT skills of students between secondary school and university.

Turning then to our fourth question regarding the role of other variables in addition to the effect of learning patterns, our results show first, that there is a considerable increase in the proportion of the explained variance in self-perceived ICT skills if we use the more complex model composed of learning patterns, gender and attendance of ICT courses. Although much research (e.g., Attewell 2001; Colley and Combe 2003; Losh 2004; Van Dijk 2006) shows the importance of gender for the explanation of different applications of ICT skills in our society, it should be checked whether this factor has the same meaning in all kinds of societies. Indeed, the digital-differentiation approach stresses the capacity of people to interpret ICT, which is situationally determined.

The social background of the students (as determined by the occupations of their parents) seems to be of less importance. In respect of the level of ICT skills, our data did not show differences between students of working-class parents and others. A more in-depth study that takes into account the economic, cultural and social capital of the different classes might offer more differentiated results.

\section{Discussion}

The body of literature concerning the interaction between learning styles and ICT skills focuses mainly on the effect of ICT-related learning styles on these skills. We hypothesised that not only context-related, but also general learning styles, would have an effect on the ICT skills of students and on the change to the level of these skills whilst at university. However, we found only a limited effect. We did know from relevant literature that the link between learning styles and ICT skills is not undiscussed: with regard to both direction and strength there is no agreement to be found. There are examples in which a similar low influence of the different learning styles of ILS was found, e.g. Gordijn and Nijhof (2002) and Lu et al. (2003). Nevertheless, it is important to point out some possible reasons as to why we found only a small effect of general learning styles on the level of ICT skills of freshmen students at university. 
To begin with, it could be that general learning patterns have no relevance for attaining a certain ICT skill, and that only context-related learning patterns can be used to find an effect. Looking at the 10 important capabilities that, according to the National Research Council (USA), each individual should possess, several can be linked with what was included in the items covering our two investigated learning patterns, meaning-directed, and applicationdirected learning (Kaminski et al. 2009, p. 229). For instance, engaging in sustained reasoning, managing complexity, testing solutions, managing problems in faulty solutions, organising and navigating information structures and evaluating information, etc. The terminology in our questionnaire was not the same, but covers these ideas. This might bring us to the following hypothesis: by using items that show a direct link between the learning patterns and the ICT skills, it is more likely that the proportion of variance in ICT skills explained by learning patterns will be larger than the results of our survey. For instance, the second item of Figure 3 could be rephrased to: To test my learning progress in ICT, I try to solve problems about ICT that I make up myself. This hypothesis finds support in interviews of 83 Taiwanese college students as reported by Tsai (2009). Although Tsai used labels similar to ours, the labels do not refer always to the phenomena investigated in our survey. Tsai observed that students differentiated between "conceptions of learning" and "conceptions of web-based learning". In both categories, the following conceptions are used: increase (web-based learning helps to expand my knowledge), applying (web-based learning involves more applications of knowledge than of theoretical concepts), understanding (web-based learning offers a broader understanding of the world), and seeing in a new way (web-based learning helps one to understand the world from another perspective). The general conceptions of learning have similar content but do not refer to web-based learning. Of 83 students, Tsai found 31 with a consistent opinion about the general conceptions of learning and web-based learning, eight students with lower-order conceptions of web-based learning than those of general learning, and 44 with more advanced conceptions of web-based learning than of general learning. These figures suggest the possibility, by connecting learning patterns directly with ICT, that the explanatory power of learning patterns for ICT skills could be higher than what we have seen in our survey. A similar remark is made by Sancho-Thomas et al. (2009, p. 530). Having set up a program to promote collaborative learning among university students for Problem Based Learning, application-directed and meaning-directed students scored higher than the other students. The researchers conjecture at the end that the results could have been better if the teams of students had been set up based on learning styles related to teamwork. More research is needed to check these hypotheses. 
Another possible explanation for the weak effects found could be methodological issues. Miller (2005) contends that the instrument used to measure the learning style and the performance of students in a computer-based introductory statistics course determined whether or not learning styles influenced achievement. We used ILS as measuring instrument, but as indicated above, we did not use all the learning patterns suggested by the instrument and hence did not include all the scales or items of the instrument.

With regard to the measurement of the ICT skills, we must note that the use of currently very popular applications (e.g. Facebook, Twitter, etc.) was not included in our questionnaire, because we were interested in the use of elementary computer programs that form the basis for most of the current popular programs among students. Among other things, the NRC (1999, cited in Kaminski et al. 2009) mentions the following skills needed to perform certain information processing tasks: using basic operating system features, using a word processor, using a graphics and/or artwork package to create illustrations, slides, etc., connecting a computer to a network, using the Internet to find information, using a computer to communicate with others, using a spreadsheet, etc. Most of these skills are included in the four independent variables concerning ICT skills used in this article. Four scales were constructed, and each measured the ability of students to work with ICT. The first is about maintaining a computer; the second scale measures the basic skills needed to work with a computer; the third scale measures the ability to develop a website; and the fourth measures the ability to use the Internet (compare Kaminski et al., 2009). Based on factor analysis, we preferred to remove some of the measured skills because they did not fit the four scales we used for the analysis. While this reduced the complexity of the ICT skills, it created the possibility of a more coherent analysis.

A third remark with regard to the methodology used concerns the fact that the data for this research were collected by means of a self-administered web survey comprising closed ended questions. This research method has not been without criticism. Van Dijk (2006) for instance wonders: "Are self-reports valid measurements of actual skills possessed?" and refers to research showing that respondents might overestimate their capacities. This not only presents a problem for studying ICT skills and learning styles but also poses a challenge for all kinds of social research. Nevertheless, we did not use automated tracking of ICT use because 1) we were interested in the respondents' self-perceptions; 2) we wanted to collect data from all kinds of students who came from throughout the country; and 3) we were concerned about 
privacy. What we measured are the learning styles and the ICT skills as the students themselves experienced them.

In sum, our analyses show that there is only a weak link between (general) learning styles and self-perceived ICT skills. This might be related to the way we measured learning styles. But our results imply that learning styles can partially explain differences between groups of students with different characteristics. However, when it comes to explaining changes of selfperceived ICT skills within groups, the effect of learning styles seems to be very small. In other words, having a certain learning style might influence students' perception of their ICT skill, but learning styles do not influence the change in the self-perceived ICT skill of the students. Moreover, our results show that there is not much change to begin with.

These conclusions have consequences for the way in which universities implement a digital learning environment. Such an environment has to take into account differences in skills and ways of use of ICT among groups of students. Students with different learning styles will probably use and perceive ICT differently. Therefore, the digital learning environment should be easily accessible in order to allow every student to make the most use of it. Moreover, our results show that the self-perceived ICT skill of students does not increase much in the first year of their studies at university. This seems to imply that, although every student in our sample had a computer and used it, it cannot readily be expected that the basic ICT skills of students improve during the first year of their studies. One must keep in mind that students already have learning styles and ways of using ICT and that they are apparently stable and difficult to change. 


\section{References}

Alty, J. L., Al-Sharrah, A., \& Beacham, N. (2006). When humans form media and media form humans: An experimental study examining the effects different digital media have on the learning outcomes of students who have different learning styles. Interacting with Computers, doi:10.1016/j.intcom.2006.04.002.

Attewell, P. (2001). The first and second digital divides. Sociology of Education, 75 (July), 252-259.

Battalio, J. (2007). Interaction online. A re-evaluation. The Quarterly Review of Distance Education, 8 (4), 339-352.

Becker, J. D. (2006). Digital equity in education: a multilevel examination of differences in and relationships between computer access, computer use, and state-level technology policies. Education Policies Archives Analysis, 15 (3). http://epaa.asu.edu/epaa/v15n3/.

Boyle, E. A., Duffy, T. , \& Dunleavy, K. (2003). Learning styles and academic outcome: The validity and utility of Vermunt's inventory of learning styles in a British higher education setting. British Journal of Educational Psychology, 73 (2), 267-290.

Chapman, D., \& Calhoun, J. G. (2006). A validation of learning style measures: implications for medical education and practice. Medical Education, 40 (6), 576-583.

Coffield, F., Moseley, D., Hall, E., \& Ecclestone, K. (2004). Learning styles and pedagogy in post-16 training. A systematic and critical review. London: Learning and Skills Research Centre.

Colley, A., \& Comber, C. (2003). Age and gender differences in computer use and attitudes among secondary school students: what has changed ? Educational Research, 45 (2 ), 155 165.

Evans, C., \& Waring, M. (2006). Towards inclusive teacher education: sensitising individuals to how they learn. Educational Psychology, 26 (4), 499-518.

Graf, S., Lin, T., \& Kinshuk (2008). The relationship between learning styles and cognitive traits - Getting additional information for improving student modelling. Computers in Human 
Behavior, 24, 122-137.

Gordijn, J., \& Nijhof, W. J. (2002). Effects of complex feedback on computer-assisted modular instruction. Computers \& Education, 39 (2), 183-200.

Hwu, F. (2003). Learners' behaviors in computer-based input activities elicited through tracking technologies. Computer Assisted Language Learning, 16 (1), 5-29.

Jansen, B. J., Booth, D., \& Smith, B. (2009). Using the taxonomy of cognitive learning to model online searching. Information Processing and Management, 45 (6), 643-663.

Kaminski, K., Switzer, J., \& Gloeckner, G. (2009). Workforce readiness: a study of university students' fluency with information technology. Computers \& Education, 53 (2), 228-233.

Kennedy, G. E., Judd, T. S., Churchward, A., \& Gray, K. (2008). First year students' experiences with technology: Are they really digital natives? Australasian Journal of Educational Technology, 24 (1), 108-122.

Kirkwood, A., \& Price, L. (2005) Learners and learning in the 21st-century: what do we know about students' attitudes towards and experiences of information and communication technologies that will help us design courses? Studies in Higher Education, 30 (3), 257-274.

Leahy, M., \& Twomey, D. (2005). Using web design with pre-service teachers as a means of creating a collaborative learning environment. Education Media International, 42 (2), 143 151.

Lee, M. W., Chen, S. Y., Chrysostomou, K., \& Liu, X. (2009). Mining students' behavior in web-based learning programs. Expert Systems with Applications, 36 (2), 3459-3464.

Liegle, J. O., \& Janicki, T. N. (2006). The effect of learning styles on the navigation needs of Web-based learners. Computers in Human Behavior, 22 (5), 885-898.

Losh, S. C. (2004). Gender, education, and occupational digital gaps 1983-2002. Social Science Computer Review, 22 (2), 152-166.

Lu, J., Yu, C. S., \& Liu, C. (2003). Learning style, learning patterns, and learning performance in a WebCT-based MIS course. Information \& Management, 40 (6), 497-507.

Masiello, I., Ramberg, R., \& Lonka, K. (2005). Attitudes to the application of a web-based 
learning system in the microbiology course. Computers \& Education, 45 (2), 171-185.

McClelland, B. (2001). Digital learning and teaching: evaluation of developments for students in higher education. European Journal of Engineering Education, 26 (2), 107-115.

Miller, L. M. (2005). Using learning styles to evaluate computer-based instruction. Computers in Human Behavior, 21 (2), 287-306.

Ross, J. L., Drysdale, M. T. B., \& Schulz, R. A. (2001). Cognitive learning styles and academic performance in two past secondary computer application courses. Journal of Research on Computing in Education, 33 (4), 400-412.

Sabry, K., \& Baldwin, L. (2003). Web-based learning interaction and learning styles. British Journal of Educational Technology, 34 (4), 443-454.

Sancho-Thomas, P., Fuentes-Fernandez, R., \& Fernandez-Manjon, B. (2009). Learning teamwork skills in university programming courses. Computers \& Education, 53 (2), 517 531.

Shaw, G., \& Marlow, N. (1999). The role of student learning styles, gender, attitudes and perceptions on information and communication technology assisted learning. Computers \& Education, 33 (4) pp. 223-234.

Sheard, J., \& Lynch, J. (2003). Accommodating learner diversity in web-based learning environments: imperatives for future developments. International Journal of Computer Processing of Oriental Languages, 16 (4), 243-260.

Shen, J., Hiltz, S. R., \& Bieber, M. (2008). Learning strategies in online collaborative examinations. IEEE Transactions on Professional Communication, 51 (1), 63-78.

Smith, J. (2002). Learning styles: fashion fad or a lever for change? The application of learning style theory to inclusive curriculum delivery. Innovations in Education and Teaching International, 39 (1), 63-70.

Strøms $\varnothing$, H. I., Grottum, P., \& Lycke, K. H. (2004). Changes in student approaches to learning with the introduction of computer-supported problem-based learning. Medical Education, 38 (4), 390-398. 
Sun, K., Lin, Y., \& Yu, C. (2008). A study on learning effect among different learning styles in a web-based lab of science for elementary school students. Computers \& Education, 50 (4), 1411-1422.

Tsai, C. C. (2009). Conceptions of learning versus conceptions of web-based learning: The differences revealed by college students. Computers \& Education, 53 (4), 1092-1103.

Van Braak J.P. (2004). Domains and determinants of university students self-perceived computer skill. Computers \& Education, 43 (3), 299-312.

van Dijk, J. A. G. M. (2006). Digital divide research, achievements and shortcomings. Poetics, 34 (4-5), 221-235.

Vandenberg, R. J., \& Lance, C. E. (2000). A review and synthesis of the measurement invariance literature: suggestions, practices, and recommendations for organizational research. Organizational Research Methods, 3 (4), 4-70.

Vermetten, Y. J., Lodewijks, H. G., \& Vermunt, J. D. (1999). Consistency and variability of learning strategies in different university courses. Higher Education, 37 (1), 1-21.

Vermunt, J. (1994). Scoring key for the inventory of learning styles (ILS) in higher education. Tilburg: Tilburg University.

Vermunt, J. D. (1996). Metacognitive, cognitive and affective aspects of learning styles and strategies: a phenomenographic analysis. Higher Education, 31 (1), 25-50.

Vermunt, J. D. (2005). Relations between student learning patterns and personal and contextual factors and academic performance. Higher Education, 49 (1), 205-234.

Vermunt, J. D., \& Minnaert, A. (2003). Dissonance in student learning patterns: when to revise theory? Studies in Higher Education, 28 (1), 49-61.

Vermunt, J. D., \& Vermetten, Y. J. (2004). The patterns in student learning relationships between learning strategies, conceptions of learning, and learning orientations. Educational Psychology Review, 16 (4), 359-384.

Wang, X. C., Hinn, D. M., \& Kanfer, A. G. (2001). Potential of computer-supported collaborative learning for learners with different learning styles. Journal of Research on 
Technology in Education, 34 (1), 75-85.

Wang, Y. H., Tseng, M. H., \& Liao, H. C. (2009). Data mining for adaptive learning sequence in English language instruction. Expert Systems with Applications, 36 (4), 7681-7686.

Wang, Yi-Shun., Wu, Ming-Cheng, \& Wang, Hsiu-Yuan (2009). Investigating the determinants and age and gender differences in the acceptance of mobile learning. British Journal of Educational Technology, 40 (1), 92-118.

Wierstra, R. F. A., \& Beerends, E. P. M. (1996). Leeromgevingspercepties en leerstrategieën van eerstejaars studenten sociale wetenschappen. Tijdschrift voor Onderwijsresearch, 21 (4), 306-322.

Zualkernan, I. A., Allert, J., \& Qadah, G. Z. (2006). Learning styles of computer programming students: a Middle Eastern and American comparison. Transactions on Education, 49 (4), 443-450. 